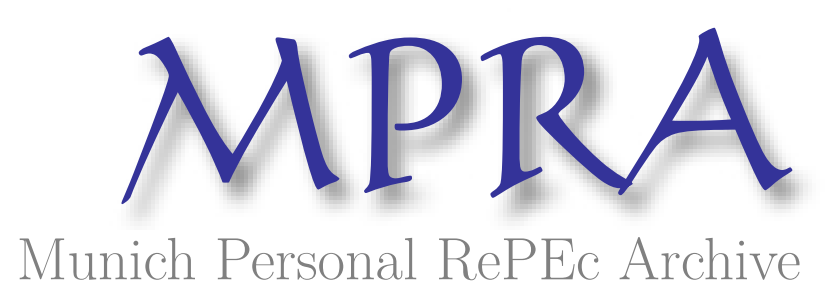

\title{
On how to define, assess and improve the governance of agro-ecosystem services
}

Bachev, Hrabrin

Institute of Agricultural Economics, Sofia

January 2020

Online at https://mpra.ub.uni-muenchen.de/100117/

MPRA Paper No. 100117, posted 05 May 2020 15:39 UTC 


\section{On How to Define, Assess and Improve the Governance of Agro- ecosystem Services}

\section{Hrabrin Bachev ${ }^{1}$}

(Agro)ecosystem services is a „new“ term, which is rapidly and widely used in academic studies, and policies and business practices around the globe. Nevertheless, in many countries around the globe, studies associated with agroecosystem services and their „management" are at the beginning stage. This article suggests a holistic framework for defining, evaluating and improving the system of governance of agro-ecosystem services. The interdisciplinary Theory of Ecosystem Services and the New Institutional Economy are adapted, and the governance of agroecosystem services defined, various related agents identified, principle forms and mechanisms of governance classified, an adequate criterion for assessing efficiency formulated, and stages for analysis and improvement of the system of governance characterized. The proposed new approach is based on the „building up“ of a hierarchy of agro-ecosystems and services related to its different levels, and an assessment of the efficiency and complementarities of the governance modes and mechanisms, corresponding to each level of "provision“ of agroecosystem services.

Kew words: agro-ecosystems, services, governance, market, private, public modes, efficiency

JEL: Q12, Q13, Q15, Q18

\footnotetext{
${ }^{1}$ Institute of Agricultural Economics, Sofia, BULGARIA, E-mail: hbachev@ yahoo.com
} 


\section{Introduction}

The products and the variety of direct and indirect benefits that humans receive from nature and the various ecosystems (agricultural, forest, grass, desert, rural, urban, mountain, lake, river, marine, coastal, etc.) are commonly known as "ecosystem services" (MEA). This „new“ and rapidly enriching category includes different types of products and services of nature and diverse ecosystems - provisional (food for humans and animals, materials and resources for production and livelihoods, etc.), economic, a place for human life and activity, recreational, tourist, aesthetic, cultural, educational, informational, habitat, supporting, biodiversity conservation, water purification and retention, flood and fire protection, climate regulation, etc. (ИАОС; МЕA).

In the last two decades, issues related to the understanding, study, evaluation and management of ecosystem services (and „disservices“" or the reduction of those services and agroecosystem damages) have been among the most topical in scientific research, politics, and business and farming practices around the world (Adhikari et al.; Allen et al.; Boelee; De Groot et al.; Fremier et al.; EEA; FAO; Gao et al.; Garbach et al.; Habib et al.; Lescourret et al.; Laurans and Mermet; MEA; Nunes et al.; Novikova et al.; Marta-Pedroso et al.; Petteri et al.; Power; Scholes et al.; Tsiafouli et al.; Wang et al.; Wood et.al.; Zhan). The increased interest in ecosystem services is a result of the fact that this emerging concept allows us better understand the factors and goals of sustainable (agrarian) development. In addition, throughout the world, including the EU and Bulgaria, ecosystems and their services are constantly degraded as a result of diverse human activity (EEA, INRA, UN). This requires public intervention (monitoring, regulation, support, evaluation, etc.) and private and collective action for their preservation, restoration and improvement (Bachev; EU; FAO; UN).

Agricultural ecosystems of different types and their specific (agro-ecosystem) services are among the most widespread in the world, as well as in Bulgaria (ИAOC; EЕA; FAO). By definition, ,agrarian“" ecosystems and ,agrarian“ ecosystem services are those that are related to agrarian ,production“, which as a rule is human (social) intervention in the natural order of nature. It is well known that agricultural production makes a significant contribution to the conservation, restoration and enhancement of ecosystems and their services, but also to their degradation and demolition (,agricultural disservices“). Therefore, services related to agricultural production and agro-ecosystems are among the most intensively studied, mapped, evaluated, regulated and stimulated. Various public intervention measures (regulations, support, standards, quotas, subsidies, payments, contracts, institutions, etc.) and programs (land use and landscape development schemes; water management; biodiversity conservation; reduction of greenhouse and other gases; integrated eco-management, etc.) are also implemented, related to their maintenance and improvement. There is also wide spreading various private, business and collective initiatives and forms for „ecological intensification“ and improving the management of (agro) ecosystem services of a given type, a combination of several types or as a whole.

Despite the significant progress in this ,new“ area, most studies are usually focused on a single agro-ecosystem service, without taking into account synergies, tradeoffs, and the needs for integrated management of aggregate ecosystem services and disservices. An uni-disciplinary approach is broadly applied, with most of the studies limited to „purely“ agronomic, environmental, technological, economic, etc. aspects of management. The later does not allow a proper identification of the spectrum of agro-ecosystem services, assessment of their integral socio-economic and ecological importance, and understanding of the driving (institutional, economic, behavioral, ideological, political, environmental, etc.) factors of their evolution. 
Studies are limited to a specific form of management (public program, government subsidy for eco-activity, quotas for resources or emissions, tax preferences, eco-contracts, ecocooperatives, industry standards, professional codes of conduct, eco-certification, market trading) or level of management (farm, eco-system, industry, region) without taking into account the interdependence, complementarity and/or competition of different governing structures. The rich diversity and complementarity of alternative (practically used and other feasible) modes of governance (market, contractual, private, collective, public, trilateral, national, transnational) are ignored, while they increasingly ,govern“ much of the activity and behavior of agrarian and nonagrarian agents related to ecosystems. Also widely used are complex forms such as multilateral, multi-level, reciprocal, interlinked, and hybrid forms are not accounted form. Only the public and formal forms and mechanisms of governance are studied, while important informal institutions and organizations are not included in the analysis.

The management of activities related to (agro) ecosystem services is studied in isolation and not as an integral part of the overall management of the agrarian and total activities of farms, rural households, professional organizations, agrarian and related businesses, local authorities, etc. A „normative" related to some ,ideal" or „model in other countries, industries, regions" and the „institutionally neutral“ („Nirvana“) approach dominates. The specific formal and informal forms, rules, rights and restrictions, and the efficiency of their enforcement and modernization are not taken into account. Agrarian and non-agrarian agents are studied as ,perfectly rational“ and „equally interested“ in achieving the common (eco) goals, rather than with different interests, knowledge, skills, capabilities, positions, costs and benefits, etc. The "comparative institutional" analysis and assessment of the efficiency of practically possible governance alternatives in the specific socio-economic and natural conditions of a country, region, sector, community, ecosystem, etc. are not evaluated. This leads to multiple market, private and public "failures“ in the area of eco-management.

Significant interactions between ecosystem services and the system of governance determining the ,socially preferred“ level of costs and benefits are not specified on an appropriate temporal, spatial, institutional and hierarchical scale. The „state“ instead of the "flow" of ecosystem services is evaluated, and space-time lags and spillovers are not considered. Economic and overall estimates are usually limited to direct (,production“) costs, neglecting significant indirect (third party, social) and „transaction“ costs. As a result, understanding and management of (agro) ecosystem services is deterred. Neither effective scientific support for improving public policies and programs, and individual, business and collective action for sustainable development can be given.

In Bulgaria, with a very few exceptions (Башев; Башев и др.; Казакова; Недков; Николов; Тодорова; Bachev; Grigorova and Kazakova; Todorova, ИАОС; Йорданов и др.; Чипев и др.) almost there are no systemic studies on the governance of agroecosystem services. The goal of the article is to present a holistic approach for defining, analyzing and improving the governance of agro-ecosystem services for the specific conditions of the country. 


\section{Definition and Agents of the Governance of (Agro)-ecosystem Services}

Maintaining, restoring and improving the services of (agro) ecosystems requires an effective social governance (a good governance) - a system of mechanisms and forms that regulate, coordinate, stimulate and control the behavior, actions and relationships of individual agents related to ecosystems and their services at various levels (Башев; Bachev). The system of governance of agro-ecosystem services is a part of the specific system of management of agricultural production and includes: different agrarian (farm managers, resource owners, hired labor) and non-agrarian (agrarian and related businesses, consumers, residents and visitors to rural areas, interest groups, administration, politicians) agents; and the various mechanisms and forms for governance the behavior, activity, relationships and effects of these agents.

The agents of governance of agroecosystem services and the specific type of their relationships, interests, goals, opportunities, position, dependencies, effects and conflicts, are to be properly identified. At the present stage of development, the agricultural production is carried out by different types of farms - individual, family, cooperative, corporate, public, etc. The farm is the main organizational unit in agriculture that manages resources, technologies and activities and produces a variety of products, including the positive and negative services of agroecosystems. The governance of agro-ecosystem services is an integral part of the management of agricultural farm, and the farm - the first (lowest) level for agro-ecosystem services management. Regardless of its specific socio-economic form, the system of governance of agro-ecosystem services will always include the farmer as a key element and aim at improving his/her environmental conservation activities and behavior.

Farm borders rarely coincide with the (agro) ecosystem boundaries. A particular farm usually includes one or more agro-ecosystems (agricultural parcel/section, and less frequently entire land in the area), and at the same time it is a part of one or more different type larger (agro) ecosystems (mountainous, plain, riparian) (Figure 1). Therefore, a major portion of agroecosystem services is a "co-production" of a group of independent farms with different capabilities and interests, which necessitates an over (extra)farm management of "collective" actions of different farms in order to effectively supply certain ecosystem services. In addition, the individual farm often produces undesirable for other ecosystems "products" (waste, pollution of water, air, etc.), necessitating special "management" outside farm gates for stimulating behavior to eliminate or minimize the negative effects of agro-ecosystems services.

Farms of different types (self-sufficient, part-time, market-oriented, member-oriented, organic, leisure) have different interests and potential for maintaining agro-ecosystem services. They have different purposes of existence - additional or basic income, profit, leisure, conservation of nature or farm for future generations, etc. Farms also have unequal incentives and opportunities (resources, knowledge, time horizon, positions) for sustainable agriculture. For an individual farm (owner-farmer) there is a "complete" alignment of the ecological objectives of the holding and the possibility for "self-management" of the produced and "internally" consumed and commercialized agro-ecosystem services. However, it has no incentive to make an effective contribution to ecosystem services consumed outside the holding as well as most often opportunities (sizes, resources, positions, time horizon) to realize all eco-functions on an effective scale. The later requires "outside" intervention (support, compensation, regulation) by the state, a third party, etc., and collective action (cooperation) of many farms to achieve the minimum size for efficient production of agro-ecosystem services of a particular kind. Bigger complex holdings (partnerships, cooperatives, corporations, state farms) and agrarian organizations with large membership have 
greater opportunities (resources, knowledge, positions, etc.), but also "internal" conflicts of interests and incentives of the various agents (owners, managers, members, hired labor). The later requires the development of a special "mechanism" for coordination and stimulation of actions, reconciling interests, resolving conflicts, etc. of the numerous agents.

Other agents also directly or "indirectly" participate in the management of agro-ecosystem services, imposing appropriate conditions, standards, norms, demand, etc., or providing positive or negative services to farmers: the owners of agricultural (land, tangible, financial, intellectual) resources that are interested in their efficient use and storage; related to agriculture business (suppliers of inputs, finance, technology, and/or buyers of agricultural products) and final consumers. These agents impose socio-economic and environmental standards, specific support and demands for environmentally sustainable farming ${ }^{2}$. Sometimes the activities of external (nonagrarian) agents adversely affect agro-ecosystem services, and require special "management" for adequate eco-behavior. The residents, visitors of rural areas, and diverse interest groups also "set" conditions (pressure, demand) for environmentally friendly farming and rural areas. The state and local government, international organizations, etc., also support sustainability initiatives of different agents and/or impose mandatory (social, economic, environmental) standards for ecoproduction and consumption.

\footnotetext{
${ }^{2}$ For example, big processors and food chains implement own strategies and standards for "sustainability", which are their own initiatives, industrial "codes of behavior" or the result of consumer pressure to "contribute" to eco-friendly production.
} 
Figure 1. Agents and Needs for Effective Management of Agro-ecosystem Services

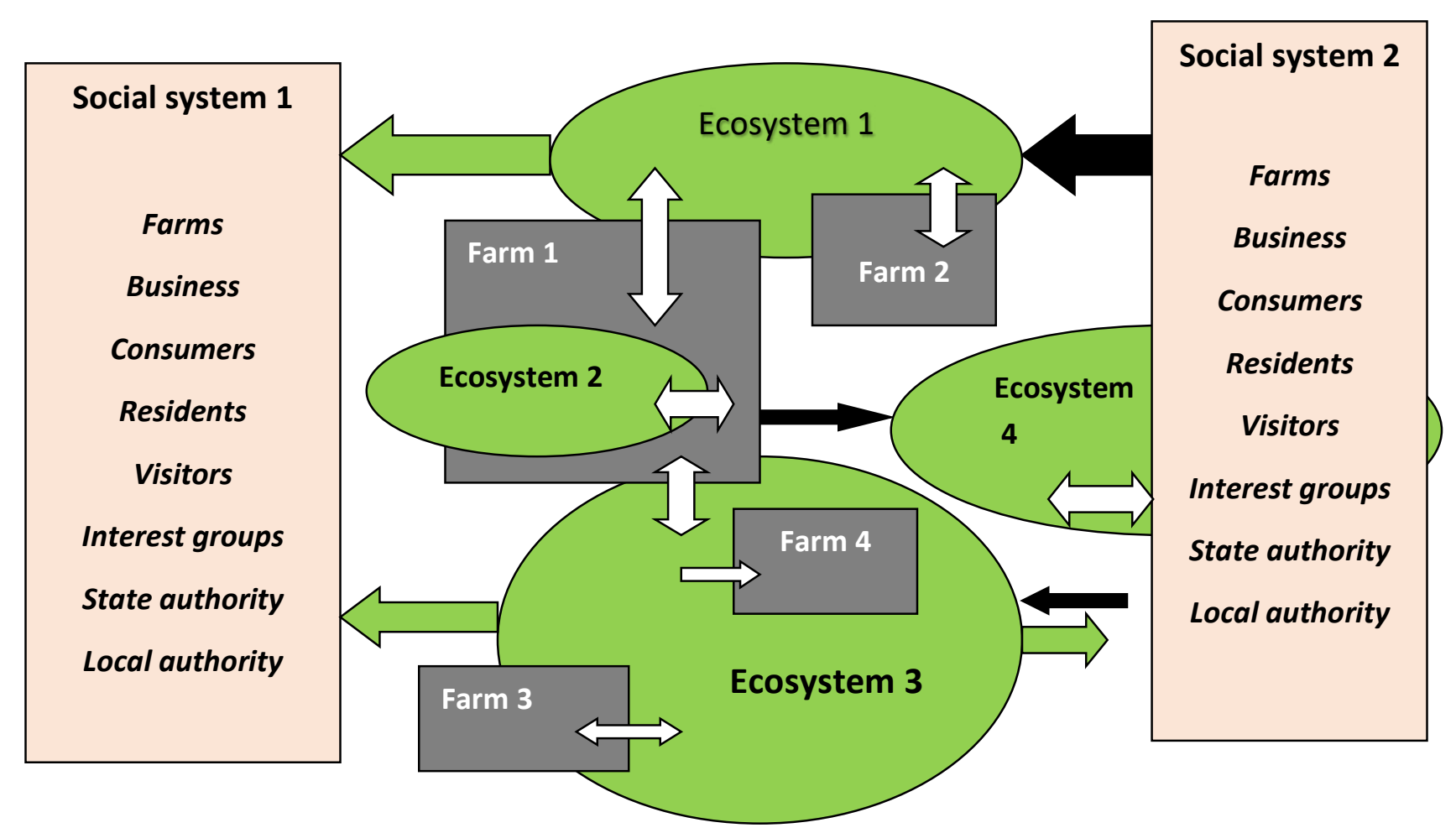

Source: author

In some cases, part of the agro-ecosystem services can be "managed" through independent actions of individual farms ${ }^{3}$. Often, however, effective eco-management requires coordinated (collective) action by a group of farms, such as the sustainable use of common grassland and limited water supply, protection of local biodiversity, etc. Farming is also often associated with significant (positive and /or negative) externalities which requires the management of relationships (co-operation, conflict resolution, cost recovery) between different farms, and growing between farmers and non-farmers. Often, agricultural contribution benefits other ecosystems (supporting and regulating ecosystem services) and a large number of residents, visitors, associated and unrelated businesses, interest groups, future generations, without the immediate benefit to "supplying" farmers - e.g. inability to commercialize due to "public" (non-profit) character of agro-ecosystem services, a long time lags and spatial differences ("lack of links") between investments and benefits received, etc. Then a public intervention is required for a sustainable supply of "production" of agro-ecosystem services. ${ }^{4}$ In all these cases, the management of agroecosystem services is far broader than simple (technical, agronomic, environmental) "relationships with nature" and includes the governance of relationships and the collective actions of agents with diverse interests, power positions, knowledge, awareness, capabilities etc. across a wide geographic, industry and time scales. Modern eco-management is increasingly associated with needs for "additional actions" (monitoring, coordination, investment) and integrated management

\footnotetext{
${ }^{3}$ For example, a good care of private farmland is typical of family farms.

${ }^{4}$ since it entails significant additional costs (investment, loss of income, etc.), the state "compensates" farmers through eco-subsidies, eco-payments, payments to disadvantaged areas, etc.
} 
of natural resources and eco-risks nationally and growing transnationally. The latter includes issues related to water and waste management, biodiversity conservation, climate change, etc., which require effective regional, national, international and global governance.

Depending on the (awareness, symmetry, strength, cost of harmonization) interests of agroecosystem services agents, there is a different need to manage eco-actions and behavior in agriculture. In Figure 1, Farm 1 must manage its actions and relationships with Farm 2, as both receive services from Ecosystem 1 and affect (positively or negatively) the supply of services to that ecosystem. Both farms must also manage their relationships with users of Ecosystem Services 1 (Social System 1) to meet aggregate demand and offset their costs of maintaining ecosystem services. Farms 1 and 2 also need to coordinate with Social System 1 to prevent conflicts with Social System 2. Farm 1 also needs to manage its relationship with Farm 3 to effectively provide services to Ecosystem 3, and manage its interaction with Ecosystem 2. Farms 1 and 3 must manage their relationships with Farm 4 and Social System 1 and Social System 2. Farm 1, which has a negative impact on services of Ecosystem 4, needs to manage its relationships with agents in Social System 2 in order to reconcile conflicts and provide an efficient flow of ecosystem services. Therefore, Farm 1 needs to participate in seven different management systems to ensure the efficient supply of services to the ecosystems to which the farm belongs or affects.

Unlike management of "pure" agricultural activities (where "simple" private and market mechanisms work well), the effective governance of agro-ecosystem services activities often requires complex, multilateral, and trilateral forms and multi-level governance. For example, the farmer's involvement in the "organic product" chain will coordinate the relationship between producers and finale consumers. However, the positive impact on agro-ecosystem services will be negligible unless also a form of coordination of relations (collective actions) with other farmers in an area or ecosystem is established. 


\section{The Hierarchy of Agro-ecosystems}

The analysis of the system of governance of agro-ecosystem services requires a proper definition of the agro-ecosystem hierarchy and the specific services of each of its levels in a particular country, region, etc. The minimum relatively separate agro-ecosystem in Bulgaria (loke in most of the countries) is the agricultural land plot or section (in the case of a closed/built-up area such as a livestock barn, a greenhouse, a beehive, a mushroom production facility, etc.) (Figure 2). This (agro) ecosystem contains a number of non-agricultural micro-ecosystems (a lake, anthill, etc.) which contribute to the production of agro-ecosystem services fi the farmland plot and larger ecosystems of which they are part, simultaneously using the services of the ecosystem farmland plot and larger agricultural and non-agricultural ecosystems.

Figure 2. Hierarchy of Agro-ecosystems - the case of Bulgaria

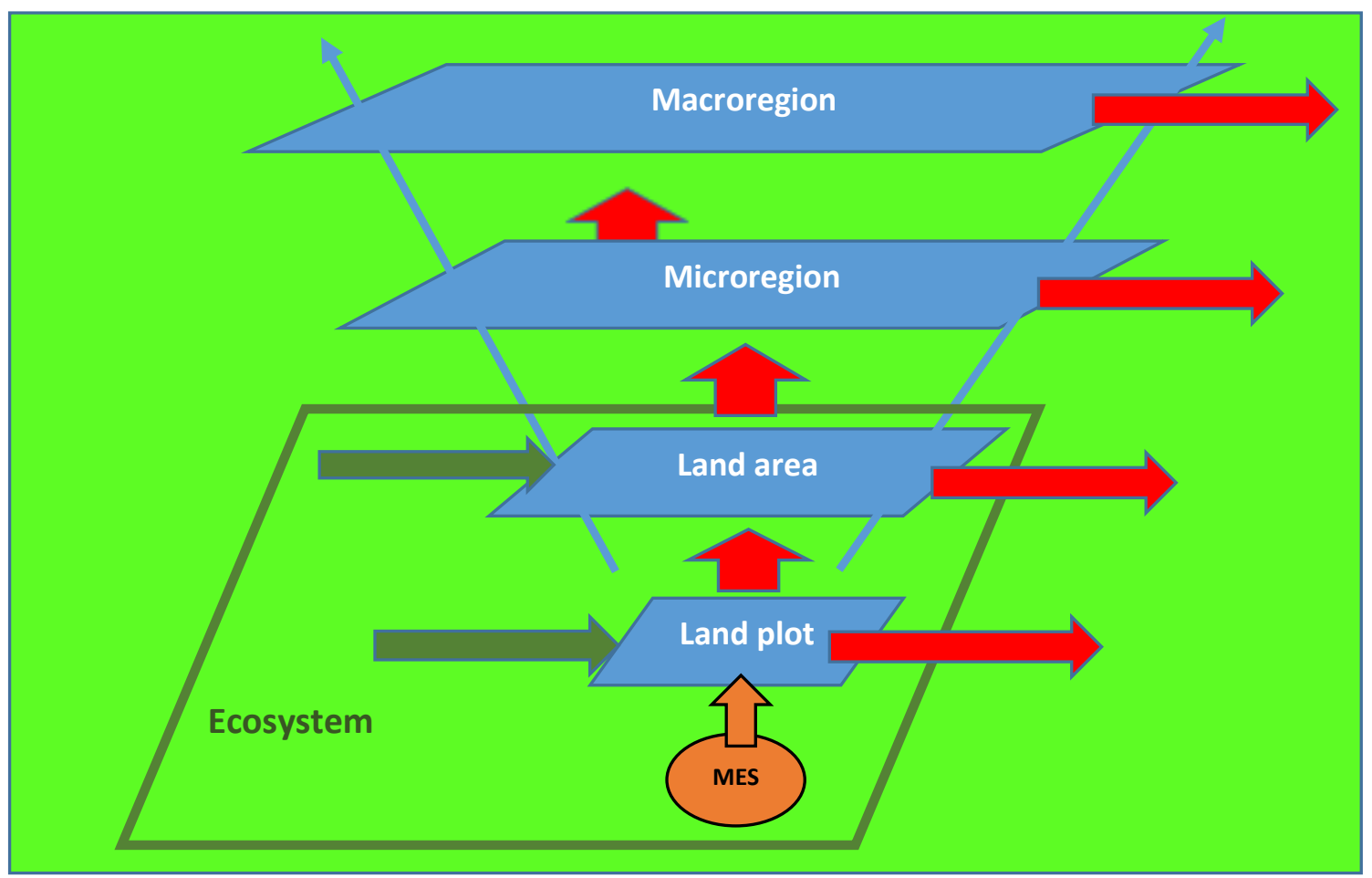

Blue - agro-ecosystem, Red - Agroecosystem Services, MES - Micro ecosystem located in the land plot, Green - Services of non-agrarian ecosystems

Source: author 
Like any agro-ecosystem, the ecosystem "agricultural land plot/section" produces products and services that are consumed by it, other agricultural and non-agricultural ecosystems, or by humans (production of foods and income, conservation of biodiversity and traditions, aesthetic, educational or scientific value, etc.). Often, agro-ecosystems at this level are a source of significant negative services affecting themselves, other agrarian and non-agricultural ecosystems, and humans (pollution of waters, air, soils, and farm produce, soil erosion, etc.). Usually, services at the first hierarchical level of agro-ecosystems are an integral part of the (positive, negative) services of larger agrarian and non-agrarian ecosystems, of which they belong. Like any agroecosystem, the agricultural land plot/section consumes or is adversely affected from (pollution, competition for natural resources, etc.) the "services" of other or larger ecosystems, of which it belongs.

The second distinct hierarchical level of agrarian ecosystems is land area (землище), which is an aggregate of numerous agricultural land plots and sections. At this level, important for the nature and society functions of (agro) ecosystems are often realized, such as: preserving soil fertility, preserving and purifying water, preventing fires and floods, etc. The next relatively distinct level of agroecosystems is micro-region ${ }^{5}$ which is characterized by its own agro-ecosystem services. Some of the agroecosystems- micro-region are within protected areas and territories of the Pan-European ecological network NATURA 2000, and provide irreplaceable (joint) service habitat and conservation of certain endangered wild plant or animal species(s).

The next hierarchical level of agroecosystems is macro-region characterized by its specific (agro) ecosystem services ${ }^{6}$. Some of these (borderline) agro-ecosystems fall into territories of two or more countries. At higher hierarchical levels, agro-ecosystems are grouped into megaregions of different types - specific (agro-ecosystems in the Danube river basin, in the Black Sea basin, in Southeastern Europe), sectoral (field crops, permanent crops, grasslands, etc.), generic (plain, semi-mountainous, mountainous, riparian, coastal, urban, rural, etc.), etc. Finally, agroecosystems can be grouped in meta-regions such as Europe, the Northern Hemisphere, global. The most important contemporary eco-challenges (waste management, global warming, climatic excesses, droughts and fires, torrential rains and floods, the spread of diseases and pests, etc.) can only be mitigated by governing (agro) ecosystem services at mega and/or meta level.

Despite many conventionalities and uncertainties, the modern science has sufficiently reliable methods to categorize (agro) ecosystems, and to "accurately" identify and "measure" the processes and mechanisms for the production, maintenance, degradation and destruction of (agro) ecosystem services of various kinds, an across different spatial and temporal scales (FAO; Fremier et al.; Gao et al.; Gemmill-Herren; Kanianska; MEA; Munang et al.; Petterri et al.; Power; Scholes et al.; Tsiafouli et al.; VanOudenhoven et al.; Wood et al.). In Bulgaria, the system of "Good Agricultural Practices" describes in detail the science-based methods, technologies, behavior, etc. that farmers should follow to keep agro-ecosystems and their services in good condition (MЗXГ, CCA). Official categorization and mapping of ecosystems in the country is done by the Environmental Protection Executive Agency, which contains ecosystems of different types (including arable land and pastures) and their services (ИАОС). The comprehensive identification, categorization and evaluation of the specific services of each particular system is to a subject of a specific interdisciplinary study, in which economists must also participate. For example, Figure 3 presents the specific (agro) and combined services of agro-ecosystems in the Western Stara Planina

\footnotetext{
${ }^{5}$ Fo instance, Sandanski-Petrich hollow, Samokov, etc. which are well-known with Melnik vine, Samokov potatoes, Melnik and Samokov cultures, traditions and landscape, recreation and tourisms, etc

${ }^{6}$ E.g. Tracia Lowland, Western Stara Planina, the Valley of Struma river, etc.
} 
(Balkan Mountains).

After specifying (the type and hierarchy of) agro-ecosystems and classifying their diverse services, the agents involved in the provision and consumption of services from each agroecosystem should be identified, as well as the mechanisms that govern the actions and relationships of related agents with each kind of ecosystem service. This is the subject of a proper in-depth (micro and macro) economic study.

Figure 3. Services of Agro-ecosystems in Western Stara Planina (WSP)

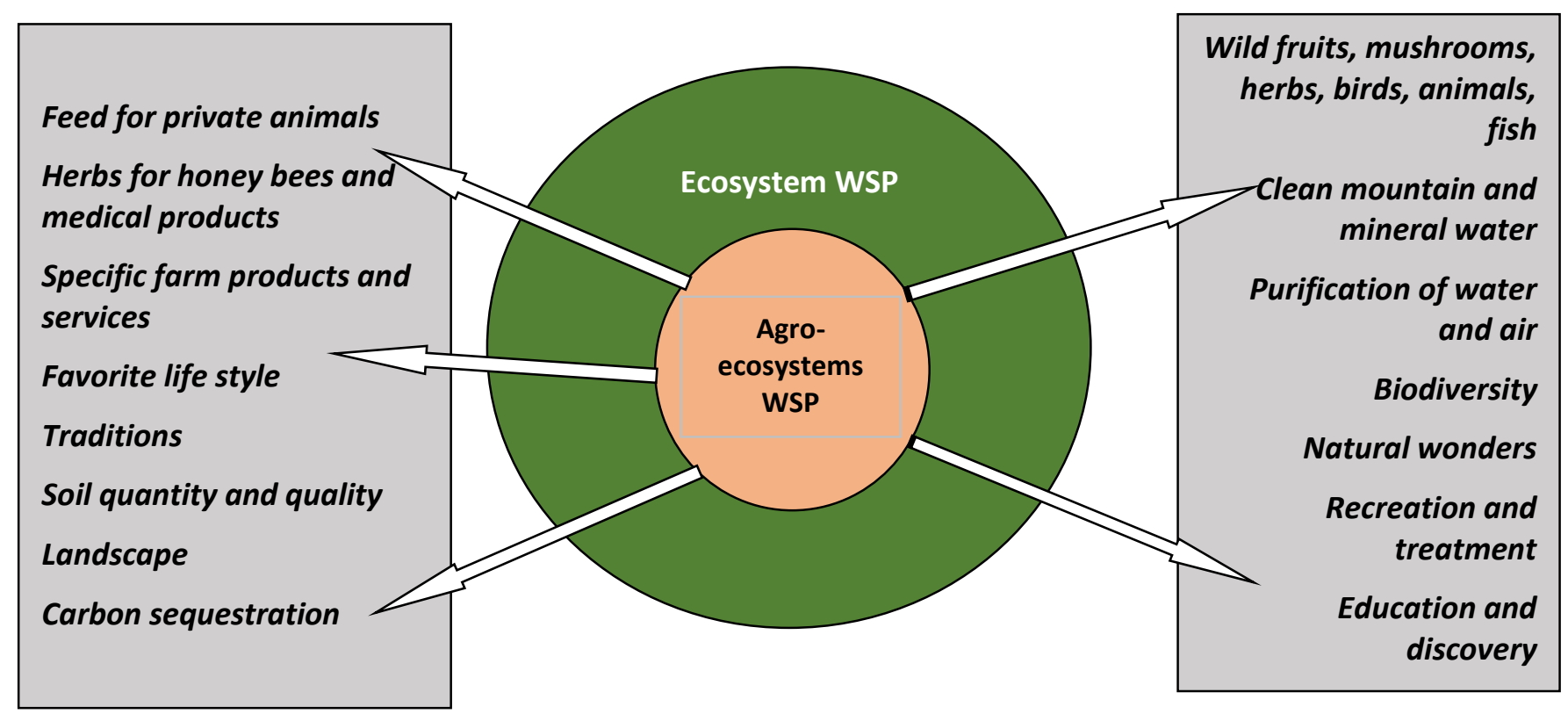

Source: Башев 


\section{Mechanisms and Modes of Governance of Agro-ecosystem Services}

The system of governance of agro-ecosystem services includes several principle mechanisms and forms that "manage" the behavior and activity of individual agents and ultimately determine the level of agro-ecosystem services (Figure 4):

First, institutional environment ("Rules of the game") - that is the distribution of rights and obligations between individuals, groups and generations, and the system of enforcement of these rights and rules (Furuboth and Richter; North). The spectrum of rights may include tangible and intangible assets, natural resources, activities, clean nature, food and eco-security, internal and inter-generational justice, etc. Enforcement of rights and rules is done by the state, social pressure, trust, reputation, private forms, or self-sanctioned by agents. Some of the rights and rules are determined by formal laws, regulations, standards, court decisions, etc. There are also important informal rules and rights established by tradition, culture, religion, ideology, ethical and moral norms, etc. The institutional "development" is initiated by public (state, community) authorities, international actions (agreements, support, pressure), and private and collective action by individuals. Modern development is characterized by the constant expansion of various eco-rights and obligations, including the granting of welfare rights to animals, wild plants and animals, and to entire ecosystems ${ }^{7}$. Institutions and their modernization create unequal incentives, constraints, costs and conflicts for: protecting and improving agro-ecosystem services, intensifying ecoexchange and cooperation, enhancing eco-productivity, inducing private and collective ecoinitiatives and investments, developing new eco- and related rights, reducing eco-disparities between social groups and regions, responding to environmental challenges, fair distribution of natural resources, etc.

\footnotetext{
${ }^{7}$ Recent trend is providing rights of legal person on entire ecosytems - initialy in Pensilvania, USA 13 years ago, followed by other countries like Bolivia, Ecvador, Bangladesh, etc.
} 
Figure 4. Modes and Mechanisms for Governing of Agro-ecosystem Services

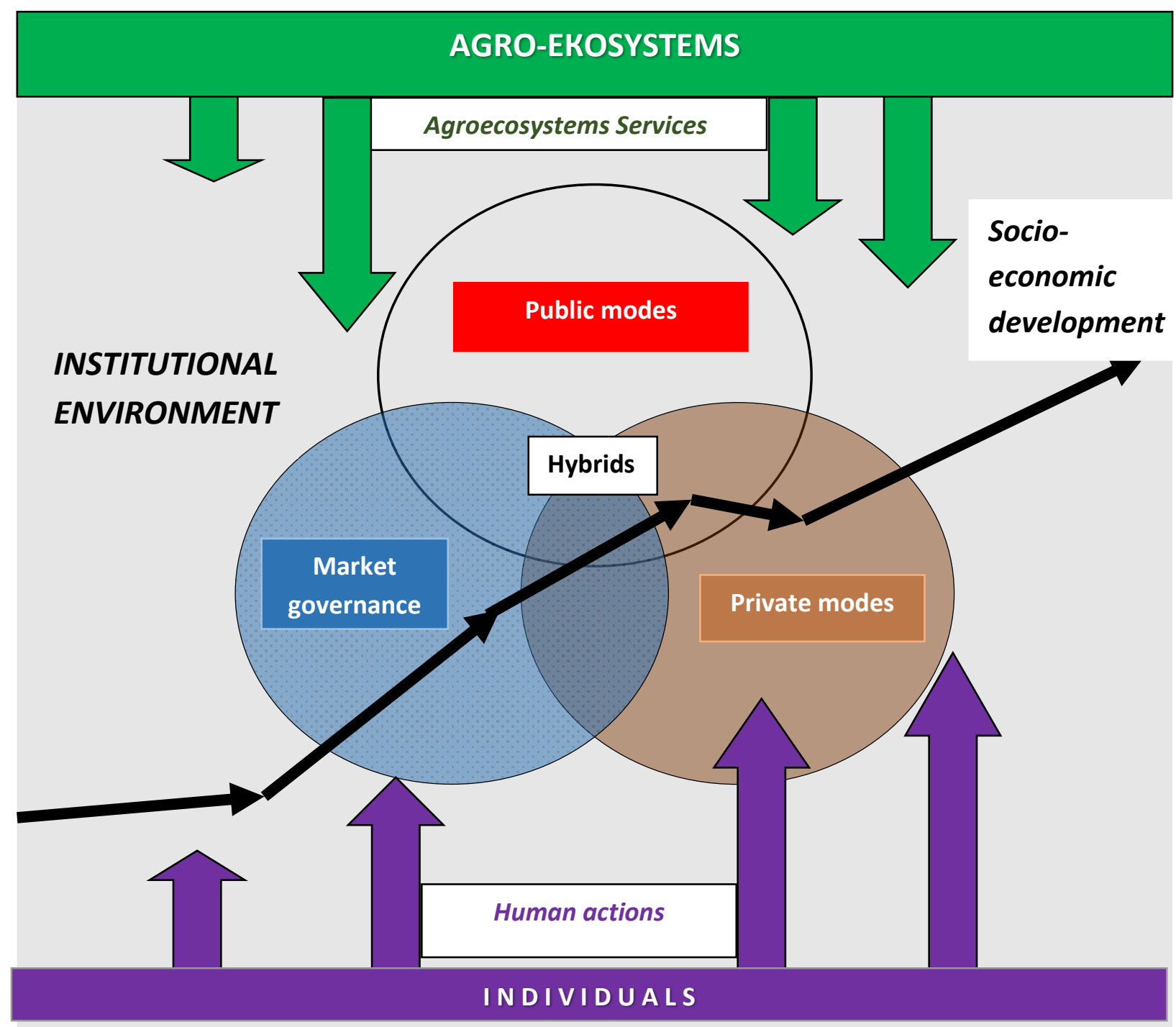

Source: author

Second, market forms ("the invisible hand of the market") - a variety of decentralized initiatives driven by the movement of "free" market prices and market competition such as: spotlight exchange of eco-products and services, classical contract for purchase, rent or sale, production and trade with special high quality, organic, etc. products and origins, ecosystem services, etc. (Table 1). The importance of the free market for coordinating (directing, correcting) and stimulating activity, exchange and allocation of resources is well known. However, there are many examples of lack of individual incentives, choices and/or unwanted "exchanges" related to environmental conservation and ecosystem services - missing markets, monopoly or power relationships, positive or negative externalities, etc. The free market "fails" in the effective management of the overall eco-activity, exchange and investment of individuals and leads to low environmental sustainability. 
Table 1. Market, Private and Collective Modes of Governance of Agro-ecosystem Services in Bulgaria

\begin{tabular}{|c|c|c|c|}
\hline Market forms & $\begin{array}{c}\text { Voluntary Private } \\
\text { initiatives }\end{array}$ & Special Private Contract & $\begin{array}{c}\text { Special Private } \\
\text { Organization }\end{array}$ \\
\hline $\begin{array}{l}\text { Spotlight sales; } \\
\text { Classical contracts; } \\
\text { Eco-visits, hunting, } \\
\text { fishing, collecting wild } \\
\text { plants and animals; } \\
\text { Organic products; } \\
\text { Special origins and } \\
\text { protected origins; } \\
\text { "Fair trade" products; } \\
\text { Farm-gate Sale; } \\
\text { Own harvesting by the } \\
\text { client; } \\
\text { Farm eco-training; } \\
\text { Eco-tourism, horseback } \\
\text { riding, fishing; } \\
\text { Eco-restaurants }\end{array}$ & $\begin{array}{l}\text { Movements for } \\
\text { Sustainable } \\
\text { agriculture; } \\
\text { Voluntary "Codes for } \\
\text { eco-behavior"; } \\
\text { Voluntary standards; } \\
\text { "Good will"; } \\
\text { Charity actions }\end{array}$ & $\begin{array}{l}\text { Eco-contracts } \\
\text { cooperative agreements } \\
\text { between farmers and } \\
\text { interested businesses or } \\
\text { communities involving } \\
\text { payment for ecosystem } \\
\text { services and resulting in } \\
\text { production methods } \\
\text { (improved pasture } \\
\text { management, reduced use } \\
\text { of agro-chemicals, } \\
\text { conservation of wetlands), } \\
\text { limiting water pollution, } \\
\text { protection against floods } \\
\text { and fires, etc.; } \\
\text { Joint investment in eco- } \\
\text { projects and ecosystem } \\
\text { services }\end{array}$ & $\begin{array}{l}\text { Family farms; } \\
\text { Cooperative farms; } \\
\text { Agro companies; } \\
\text { Public farms; } \\
\text { Eco-associations; } \\
\text { Eco-cooperative; } \\
\text { Specialized } \\
\text { organization } \\
\text { restoration, } \\
\text { maintenance } \\
\text { improvement and } \\
\text { ecosystem services; } \\
\text { Public-private } \\
\text { partnerships; } \\
\text { Protected Trademarks, } \\
\text { Origins, Products, etc. }\end{array}$ \\
\hline
\end{tabular}

Source: author

Third, private forms ("private or collective order") - various private initiatives and special contractual and organizational forms such as: long-term eco-contracts, voluntary eco-actions, voluntary or mandatory codes of eco-behavior, partnerships, eco-cooperatives and associations, trademarks, labels, etc. Conservation of natural resources is part of the management strategy of many agricultural (eco, green) farms. There are also many initiatives in the EU by farmers' organizations, industry, retail chains and consumer organizations that are associated with raising the environmental sustainability of agricultural production. Individual agents benefit from economic, market, institutional, etc. opportunities and overcome institutional and market failures by selecting or designing new profitable private forms (rules) to manage their behavior, relationships and exchanges. However, there are many examples of private sector "failure" in managing socially desirable activities such as eco-conservation, ecosystem services, conservation of traditional species, production, rural areas, etc.

Fourth, public forms ("public policy") - various public (community, state, international) interventions in the market and private sectors such as: public recommendations, regulations, support, taxation, financing, provision, modernization of rights and rules, etc. (Table 2). Agrarian and rural development programs are implemented which aim at "proportional" development of agriculture and regions, preserving and improving the natural environment, etc. In many cases, effective management of individual activity and/or the organization of certain activities through market mechanisms or through private contracting may take a long time, be very expensive, fail to reach the socially desirable scale size, or not take a place. Centralized public intervention could reach the desired state faster, with less cost or more efficiently. The public is "involved" in the management of agro-ecosystem services by: providing eco-information and eco-training to private agents, stimulating and (co) financing their voluntary activities, imposing mandatory eco- 
regulations and sanctions, organizing eco and related activities (state-owned eco-enterprise, research, monitoring), etc. However, there are many cases of poor public involvement (inaction, under-intervention, over-regulation) leading to significant development problems.

\section{Table 2. Forms of Public Interventions in Agro-ecosystem Services in Bulgaria}

\begin{tabular}{|c|c|c|c|c|}
\hline $\begin{array}{c}\text { New Property } \\
\text { Rights and } \\
\text { Enforcement }\end{array}$ & Public Regulations & $\begin{array}{c}\text { Public } \\
\text { Taxation }\end{array}$ & Public Support & $\begin{array}{c}\text { Public } \\
\text { Provision }\end{array}$ \\
\hline $\begin{array}{l}\text { Rights for a clean } \\
\text { and beautiful } \\
\text { environment, } \\
\text { biodiversity; } \\
\text { Private rights on } \\
\text { natural, biological } \\
\text { and } \\
\text { environmental } \\
\text { resources; } \\
\text { Collective rights } \\
\text { over irrigation } \\
\text { waters, pastures, } \\
\text { etc.; } \\
\text { Private rights for } \\
\text { profit-oriented } \\
\text { management of } \\
\text { natural resources; } \\
\text { Tradable } \\
\text { pollution quotas } \\
\text { (permits); } \\
\text { Private rights to } \\
\text { intellectual } \\
\text { products, origins, } \\
\text { (protection) of } \\
\text { ecosystem } \\
\text { services; } \\
\text { Rights for issuing } \\
\text { eco-bonds, shares } \\
\text { in ownership; } \\
\text { Private liability } \\
\text { for pollution; } \\
\text { Provide legal } \\
\text { personality rights } \\
\text { to a part or entire } \\
\text { ecosystems }\end{array}$ & $\begin{array}{l}\text { Regulations for organic } \\
\text { farming; } \\
\text { Regulations for Trading } \\
\text { Ecosystem Services } \\
\text { Protection; } \\
\text { Emissions and use quotas for } \\
\text { products and resources; } \\
\text { Regulations for the } \\
\text { introduction of alien species, } \\
\text { genetically modified crops; } \\
\text { Prohibition of certain } \\
\text { activities, use of resources } \\
\text { and technology; } \\
\text { Nutrition and pest } \\
\text { management standards; } \\
\text { Regulations to protect water } \\
\text { from nitrate pollution; } \\
\text { Regulations for biodiversity } \\
\text { and landscape management; } \\
\text { Licensing for the use of } \\
\text { water and agro-ecosystems; } \\
\text { Rules and quotas for the use } \\
\text { of sewage sludge; } \\
\text { Quality and safety standards; } \\
\text { Standards for good } \\
\text { agricultural practices; } \\
\text { Compulsory eco-education; } \\
\text { Certification and licensing; } \\
\text { Mandatory eco-labeling; } \\
\text { Identification of threatened } \\
\text { areas and reserves; } \\
\text { Set-aside measures; } \\
\text { Inspections, fines, } \\
\text { termination of activity }\end{array}$ & $\begin{array}{l}\text { Tax } \\
\text { preferences; } \\
\text { Eco-taxes on } \\
\text { emissions } \\
\text { and products; } \\
\text { Fees for } \\
\text { overproducti } \\
\text { on of } \\
\text { manure; } \\
\text { Fees on } \\
\text { manufacturin } \\
\text { g or export } \\
\text { for financing } \\
\text { innovation; } \\
\text { Waste tax; } \\
\text { Farmland tax }\end{array}$ & $\begin{array}{l}\text { Recommendatio } \\
\text { ns, information, } \\
\text { demonstrations; } \\
\text { Direct } \\
\text { payments; } \\
\text { Subsidies for } \\
\text { eco-actions of } \\
\text { farms, } \\
\text { businesses and } \\
\text { communities; } \\
\text { Preferential } \\
\text { Credit; } \\
\text { Public eco- } \\
\text { contracts; } \\
\text { Government } \\
\text { procurement } \\
\text { (water and other } \\
\text { resources); } \\
\text { Price and } \\
\text { production aid } \\
\text { for organic } \\
\text { production and } \\
\text { special origins; } \\
\text { Financing of } \\
\text { eco-education; } \\
\text { Assistance for } \\
\text { farmers and } \\
\text { environmental } \\
\text { associations; } \\
\text { Collection of } \\
\text { fees to pay for } \\
\text { provision of } \\
\text { ecosystem } \\
\text { services }\end{array}$ & $\begin{array}{l}\text { Scientific } \\
\text { research; } \\
\text { Market } \\
\text { information; } \\
\text { Agro- } \\
\text { meteorological } \\
\text { forecasts; } \\
\text { Sanitary and } \\
\text { veterinary } \\
\text { control, } \\
\text { vaccinations, } \\
\text { preventive } \\
\text { measures; } \\
\text { Public Agency } \\
\text { (Company) for } \\
\text { important } \\
\text { ecosystems; } \\
\text { Applying the } \\
\text { "precautionary } \\
\text { principle"; } \\
\text { Environmental } \\
\text { monitoring; } \\
\text { Eco-forecasts; } \\
\text { Risk } \\
\text { Assessment }\end{array}$ \\
\hline
\end{tabular}

Source: author 
Fifth, hybrid forms - some combination of the above three, such as public-private partnerships, public licensing and inspection of private bio-farms, etc. For example, the supply of many of the ecosystem services by farmers can hardly be managed through private contracts with individual consumers due to the low appropriability, high uncertainty and rare character of transactions (high costs for negotiation, contracting, payment from potential customers, disputing) (Башев). Supplying eco-services is very expensive (additional production and organizational costs) and is unlikely to be done on a voluntary basis. The financial compensation of farmers by willing consumers through a pure market form (fee, premium) is also inefficient due to the high information asymmetry and the enormous enforcement costs. A trilateral form with direct public involvement makes these transactions effective: on behalf of current and future consumers, a state agency negotiates a contract with farmers for environmental conservation service, coordinates the activities of the various agents, provides public payment to farmers for the eco-service and controls the fulfillment of the contractual conditions.

The efficiency of the individual forms of governance of agro-ecosystem services of different types is quite different since they have unequal potential to: provide adequate eco-information, induce positive eco-behavior, resolve eco-conflicts and coordinate eco-activities of different participants, improve environmental sustainability and reduce eco-risks, minimize overall ecomanagement costs (for conservation, third party, transaction, etc.), for agents with different preferences and opportunities, and in specific (socio-economic, natural) conditions of each ecosystem, community, industry, region, and country. For example, a proper eco-information and training is sufficient to induce voluntary action by a "green" farmer, while most commercial enterprises need external incentives (market premium, monetary compensation, penalties); market prices generally coordinate well the relations between suppliers and users of waters, while regulating relationships between water pollutants and users requires a special private or public form; farmers' independent actions improve the condition of local eco-systems, while solving most of (regional, national, global) eco-problems requires collective action on a large scale and time periods, etc. In the long run, the specific system of governance of the agricultural sector and sustainability (pre)determines the type and character of socio-economic development (Figure 4). Depending on the efficiency of the established system of governance of agro-ecosystem services, individual farms, sub-sectors, regions and countries achieve different results in the conservation, restoration and improvement of ecosystems, and there is a different state of natural resources, level of eco-risks and eco-costs related to the development of agricultural sector, and unequal environmental sustainability of individual farms, sub-sectors, regions, agriculture, and different countries. 


\section{Factors for Choice and Efficiency of Governance Mode}

In rare cases, there is the only practically possible form of managing activity and relationships associated with a particular agro-ecosystem service. ${ }^{8}$ Often, many alternative (market, private, public, hybrid) forms of governance are possible - e.g. the provision of a "biodiversity conservation service" can be managed: as a farmer's voluntary activity; through a private contract of the farmer with an interested/affected agent; through an interlinked contract between the farmer and the supplier/processor; through cooperation (collective action) with other farmers and stakeholders; by trading in the (free) market or through supported by a third party (certification body) trade with special (organic, protected, fair-trade) products; through a public contract specifying the farmer's obligations and compensations; through a public decree (regulation, resource/emission quotas, taxation); through a hierarchical public agency (company), or through a hybrid form.

There is no single "universal" form for governing all types of agro-ecosystem services equally, effective for all agents in diverse socio-economic and natural conditions (Башев). The choice of managerial mode for a particular service and the development of the system of agroecosystem services management depends on various factors. For example, the choice of governing form strongly depends on the personal characteristics of the farmers and other participants in the process - personal preferences, (ethical, religious) views, experience, awareness, training, willingness for association and/or risk-taking, professional and financial capabilities, reputation, trust, tendency for opportunism, power positions, age, eco-innovation, entrepreneurship, leadership, etc. Usually, younger, more educated and innovative farmers are more actively involved in various new forms of management of agro-ecosystems. The specific benefits for the individual farmer from eco-management take different forms - monetary or non-monetary income, profit, indirect economic benefits, enjoyment of eco-activity, desire to preserve nature for future generations, etc.

Another important factor is the development of science and technology, which determine the extent of awareness of the types, factors and importance of ecosystem services, provide more complete information on environmental problems and risks, and the positive and negative impact of agricultural practices, provide new opportunities for effective management of activities related to the preservation and improvement of services of agro-ecosystems of different kind (precision agriculture, digitalization, automation of monitoring, operations, etc.), etc. Digitization, for example, is revolutionizing the forms of gathering and processing information, sharing know-how, finding trading and coalition partners, "cheap" online marketing of eco-products nationally and transnationally, etc. The development of science and technology is also related to some new challenges for the system of eco-management and control associated with the use of GMOs, artificial intelligence, etc.

The choice of governance form also depends on the state of ecosystems, the character of environmental problems and risks, and the socio-economic and ecological significance of the service. As a rule, a high social value and a greater environmental risk more easily induce private coalition and more public forms of intervention (standards, subsidies, regulations, etc.). For example, the "big" problems associated with the storage of manure and sewage sludge in the

\footnotetext{
${ }^{8}$ For example, in Japanese agriculture with scattered rice paddoes, the water supply would not be possible by individual farmers (high interdependence, indivisibility of use), and therefore from the earliest times until now the organization of water retaintion and use evolvs as a public project.
} 
country led to the emergence of a new form - free delivery to using farms by the livestock complexes and water supply companies.

The choice of management form also strongly depends on market and public demand (and pressure) for the sustainable exploitation of natural resources. The nature of this demand depends on the overall socio-economic development, social importance, and priority (socio-economic and environmental) challenges at the relevant stage. Wealthy consumers and societies are willing to pay more for a wide range of ecosystem services - premium for eco-products and services, generous state and local programs for conservation of nature, cultural and historical heritage, lifestyle, etc.

The choice of governance form depends very much on the character of the service of the agro-ecosystem, the relationship between cost and benefits, and the amount of time and space lag between investment and effect. For ecosystem services with immediate benefits to the farmer and/or consumer, the market and private management works well, while those requiring long-term and large-scale investments for the production of services with a "public" goods character, it is required long-term and complex forms.

Evolution of the system of eco-management depends on the prevailing institutionally determined eco-rights, norms and obligations, and on the existing and practically possible market, private and public forms of governance. Management form is often (predetermined) by the institutional constraints, such as some form of farming, environmental, etc. activities are socially unacceptable or illegal. For example, "free\$ market and private activity in protected areas is not allowed, private ownership and trade in certain natural resources (water, genetic diversity) is not possible, etc.

Another important determinant of the system of governance are public (national, European) policies $^{9}$, as well as the implementation of international conventions and agreements on various aspects of environmental sustainability. They create a new (national, European, global) order by introducing new rights and rules, markets and directions for development.

The system of eco-management also depends on the "natural" evolution of the natural environment (global warming, extreme climate, drought, etc.), which imposes new private, collective and hybrid forms that help confrontation to negative trends and/or effective adaptation to natural (and social) changes.

$A$ "pure" economic factor that determines the choice of governing form is related to the efficiency. Individual governing modes are alternative, but not equally effective forms for organizing activities and transactions associated to a particular agro-ecosystem service. Each of them has specific advantages and disadvantages for safeguarding eco-rights and investments, and for coordination and stimulation of socially desirable eco-behavior and activities, for exploration of economies of scale and scope, for minimizing of production and transaction costs ${ }^{10}$.

In the specific natural and institutional environment, various agents can manage their relations through the free market (adapting to market prices), through negotiation (agreeing on a "private order"), through coalition (collective decision making), in an internal organization ("the hand of manager"), through a public form or hybrid organization. "Rational" agents tend to choose or design the most effective forms for governing of their relations that maximize benefits and

\footnotetext{
${ }^{9}$ Some "green" governments give high priority to environmental protection, while others prioritize economic growth at the expense of degradation and even destruction of natural resources.

${ }^{10}$ A detailed description of the advantages and disadvantages of the various forms of governance is made in our previous publication (Башев).
} 
minimize their costs. In the long run, management forms that minimize transaction costs ultimately dominate (Williamson).

In the unrealistic conditions of "zero" transaction costs and well-defined private property rights, the state of maximum efficiency is always achieved regardless of the initial allocation of rights between individuals and the form of governance (Coase). All information about the efficient exploitation of natural and technological opportunities and the satisfaction of demand would be costlessly available for everybody. Individuals would costlessly coordinate their activities and protect their (absolute and contractual) rights ${ }^{11}$, and "trade" own resources (exchange the rights on them) in the mutual interest with equal efficiency in the free market, through private organizations of different types, through collective decision-making, or in a single national hierarchy (company). Then the optimal requirements for environmental sustainability, and the maximum potential for economies of scale and scope (maximum environmental protection/improvement, and productivity of resource, "internalizing externalities"), and improving the well-being (consumption, provision of ecosystem services, etc.) would be easily, costlessly achieved. ${ }^{12}$

However, when transaction costs are significant, then the costless negotiation, exchange and protection of individual rights is impossible. Therefore, the initial distribution of property rights between individuals and groups, and their good definition and enforcement, are critical for overall efficiency and sustainability. For example, if the "right to a clean environment" is not well defined, that creates great difficulties for the effective supply of ecosystem services - costly disputes between the pollutant and affected agents; disregard for the interests of particular groups or generations, etc. Moreover, even when rights are well-defined, the eco-management is usually associated with significant transaction costs. For instance, the agents have the cost of identifying different rights and effectively protecting them (unwanted appropriation by other agents); to study and comply with the various institutional restrictions (rules, standards, rules); to collect the necessary technological, eco- and other information; to find the best partners and prices; to negotiate the terms of the exchange; for writing and registration of contracts; to enforce exchange terms through monitoring, control, measurement and safeguards; to dispute rights and agreements in court or otherwise; for adaptation or termination of agreements along with the evolution of conditions of production and exchange, etc.

Therefore, in the real world with incompletely defined and/or enforced rights and positive transaction costs, the form of agro-environmental governance becomes critical and (pre)determines the extent of degradation, conservation and enhancement of (agro) ecosystems and their services (Башев). This is because different governance structures have unequal efficiency (effect, costs) in organizing the same activities related to the production and consumption of ecosystem services in the specific socio-economic and natural environment. Often, the high transaction costs make it very difficult and even block the organization of otherwise efficient (mutually beneficial) activities and exchanges for all participants ${ }^{13}$.

Transactional costs are to be well distinguished from the "production" (agronomic, opportunity ${ }^{14}$, etc.) costs for environmental protection. In the contemporary environment, the latter

\footnotetext{
${ }^{11}$ In a world of zero transaction costs, the definition (redistribution) of the rights by individuals, groups, and society, and effective enforcement of the new rights would be easily (costlessly) achivable.

${ }^{12}$ At present stae, there is a principled agreement (a "social contract") for a global sustainable development.

${ }^{13}$ Most often, the supplier and the user of agro-ecosystem services are different agents, which implies a transaction (desired or unwanted exchange) between them.

${ }^{14}$ As "opportunity costs" for the current eco-costs can be used the missed income from the traditional or other feasible activities, while for the eco-investments - the long-term investments for restoration of natural resources or for replacement with other natural, material etc. resource.
} 
are an important economic cost that is to be recovered similarly to other "technological" costs from the beneficiaries of the preserved /improved nature. Often, that is the farmer who invests to maintain the productivity of natural resources (land fertility, water cleanliness, ecosystem services), and reimburses these costs like other investments through a stream of future benefits (productivity, profitability, market positions, etc.). Increasingly, however, these are other agents who pay for the used eco-services either directly (through the purchase of eco-products and services) or indirectly (through collective organizations, taxes and fees, etc.).

The effective forms for governing of ecosystem services optimize the overall (transaction and production costs) of agricultural activity - minimizing transaction costs and allowing (otherwise mutually beneficial) eco-exchange to be realized on a socially desirable scale; allowing the achievement of the minimum/optimal environmental requirements and/or the exploration of purely technological economies of size and scale in farming, eco- and other activities.

The "production costs" for the "provision" of agro-eco-services are relatively easy to measure. However, much of the associated transaction costs are difficult or impossible to measure. Therefore, the (most) effective form of governance is determined through Discrete Structural Analysis, according to the (combination of) critical dimensions ${ }^{15}$ of activity and transactions (Башев, Williamson). In a previous publication, we have identified the most effective market, contractual and internal forms of eco-management, depending on the critical factors of transactions and activity (Башев).

The "rational" agents tend to use and/or design such forms for governing their diverse activities and relationships that are the most effective for the specific institutional, economic and natural environment - modes that maximize their overall (production, environmental, financial, transactional, etc.) benefits and minimizing their overall (production, eco-maintaining, transaction, etc.) costs (Башев). However, the result of this private (and market) optimization of the management and the activity is not always the most efficient allocation of resources at a social scale and socially desirable (maximum possible) environmental conservation activity. Agricultural activity is often accompanied by significant undesirable negative eco-effects - soil degradation, water pollution, biodiversity destruction, air pollution, significant greenhouse gas emissions, etc., including in Bulgaria (ИАОС). The market and the private sector "fail" in effective governance of a significant proportion of transactions associated with agro-ecosystem services with low appropriability, high and unilateral specificity of investment, high uncertainty, and low repetition/frequency. There is a need for a public intervention (government, international aid) as a third party to make such eco-activities and transactions possible or more efficient. However, public intervention in (eco-)governance is not always more effective, since public failure is actually possible. In the country and around the world, there are many examples for inappropriate, excessive, insufficient, untimely or too expensive public intervention at all levels. Often, public intervention either fails to correct market and private sector failures or "corrects" them at the price of more overall costs.

The criterion for assessing the efficiency of the agro-environmental governance is to be whether the socially desirable and practically feasible eco-goals (e.g. amount of agro-ecosystem services) are achieved with the lowest possible total cost (direct, indirect, private, public, production, environmental, transactional etc.). Accordingly, inefficiency is manifested in the failure to achieve the really possible (technical, political, economic) ecological objectives (overcoming certain eco-problems, minimizing existing eco-risks, reducing eco-losses, restoring

\footnotetext{
15 Честота, неопределеност, специфичност на активите (Williamson), и присвояемост (Башев) - факторите, които причиняват вариация на транзакционните разходи между алтернативните форми за управление.
} 
and improving the natural environment, increasing agro-ecosystem services, etc.) or in achieving the set up goals with excessive cost compared to another feasible form of governance. 


\section{Stages in the Analysis and Improvement of the Governance of Agro-ecosystem Services}

The analysis and improvement of the system of governance of agro-ecosystem services should include the following steps (Figure 5):

First, the trends, factors and risks associated with (agro) ecosystems and the "supply" of agro-ecosystem services must be identified. Modern science provides sufficiently precise methods for assessing the state of ecosystems of different kind, and for identifying existing, evolving and likely problems - climate change, degradation and destruction of natural resources and ecosystems, eco-risks, etc. (MEA). Moreover, it offers reliable tools for assessing the (positive and negative) impact of agriculture on the ("health") state of nature, its main components, and ecosystem services of various types, including at different spatial and temporal scales. For example, systems of multiple eco-indicators for pressure, state, response, and impact, volume and structure of ecosystem services, integrated assessment of agro-ecosystem services, eco-sustainability of agriculture, etc. are widely applied. The absence of serious eco-problems, conflicts and risks is an indicator that an effective system for governance of agro-ecosystem services exists. In most cases, however, significant or increasing eco-problems and risks related to agricultural development are observed, as is the case with Bulgaria (ИАОС). 
Figure 5. Stages in the Analysis and Amprovement of the System of Governance of Agroecosystem services

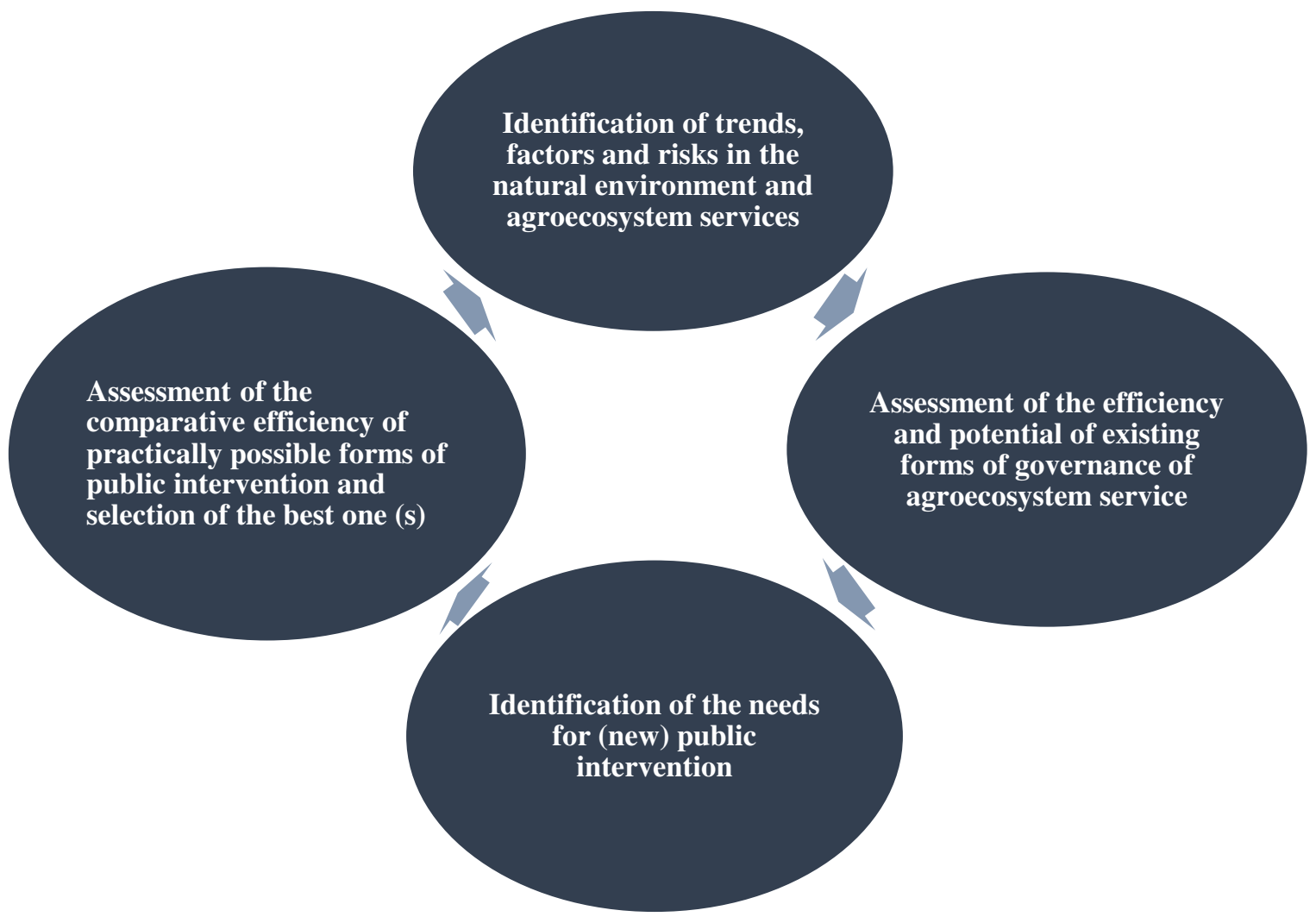

Source: author

Second, the efficiency of existing and other possible forms and mechanisms of governance for overcoming existing, evolving and possible eco-problems and risks associated with the services of agroecosystems of every type are to be evaluated. The analysis is to cover the agro-ecomanagement system and its individual elements - institutional environment and diverse (formal, informal, market, private, contract, internal, external, individual, collective, public, simple, complex, etc.) forms for governing the activities and relationships of related agents.

It is necessary to analyze the "de facto" rights over tangible and intangible assets (material and intellectual agrarian and eco-products and services), natural resources, certain activities, clean nature, food and eco-security, internal and inter-generational justice, and etc. that are relevant to the services of agro systems. The efficiency of the system of enforcement of rights and rules by the state, public pressure, trust, reputation, private and collective forms, or by agents themselves have to be also analyzed. The extent to which the institutional environment creates incentives, constraints and costs for individual agents and society to preserve, restore and improve agroecosystems and their services, to intensify eco-exchange and cooperation of related agents, to increase the productivity of resource use, to induce private and collective eco-initiatives and investments, to develop new eco-rights, to reduce disparities between different (agro) ecosystems, to overcome the socio-economic and environmental problems, conflicts and risks, etc., all are to be assessed. 
The assessment of the efficiency of individual market, private, collective, public and hybrid forms of governance is to incorporate their absolute and comparative potential for protection and development of eco-rights and investments of agents, to promote the socially desirable level of environmental behavior and activity (agro-ecosystems services), rapid identification of ecoproblems and risks, cooperation and resolution of eco-conflicts, and minimization and recovery of total eco-costs (for conservation, restoration, improvement, transaction, direct, indirect, private, public, etc.). The complementarity and/or contradiction of different modes of governance are to also be assessed - for example, the high complementarity between (some) private, market and public eco-governance forms; the contradiction between the "gray" and "light" sectors; conflicts between the agrarian and non-agrarian sectors regarding natural resources and ecosystem services, etc.

Most of applied forms of agro-management of activity affect more than one aspect of agriculture and agro-ecosystem services. In addition, improvement of one type of agro-ecosystem services (e.g. food production) through a particular form is often associated with negative effects on another type (e.g. conservation of natural biodiversity). Therefore, the overall efficiency of a given form, of a particular "package" of instruments or of the system of governance as a whole must always be taken into account.

The analysis and evaluation of the system of governance of agroecosystem services is a complex, multidimensional and interdisciplinary process that requires in-depth knowledge of the advantages and disadvantages of specific forms of governance and a detailed characterization of their efficiency (benefits, costs, effects) in the specific conditions of each agricultural agent, agricultural farm, type of farms, ecosystem, sub-sector, region, etc. Quantitative indicators are of little use here and most often a qualitative analysis of comparative advantages, disadvantages and net benefits is needed. Even when the system of agro-eco-management and agro-ecosystem services management "works well", periodic performance (efficiency) checks have to be made. This is because good environmental protection may have been achieved with excessive public expenditures, or it may have been missed a further improvement of agro ecosystem services with the same social costs. In both cases there is an alternative more effective organization of the management of agro-ecosystem services. For example, a costly for the taxpayer public ecogovernance (in terms of incentives, overall costs, adaptation and investment potential) can be replaced by a more effective private, market or hybrid form (public-private partnership).

Third, the inefficiency ("failure") of dominating market, private and public forms is to be detected, and the needs for new public intervention in the management of agro-ecosystem services of each kind identified. They may be related to the inability to achieve the socially desirable and practically possible eco-goals, the significant transactional difficulties (costs) for participating agents, the inefficient use of public funds, etc.

Finally, the alternative forms of new public intervention that can overcome existing (market, private and public) failure are to be identified; and their comparative efficiency and complementarity evaluated, and the most effective one $(s)$ selected. It is important to compare only practically (technically, economically and politically) possible forms of new public intervention in the management of agro-ecosystem services of every kind in the specific socio-economic, organizational and natural environment.

The public forms not only support (market and private) transactions, but they also associated with significant (public and private) costs. Estimates have to include all costs of implementation and transaction - direct costs (of taxpayers, supporting institution), and transaction costs (of coordination, stimulation, control of opportunism and mismanagement) of bureaucracy, and the 
costs of individuals' participation in the public forms (for adaptation, information, paperwork, fees), and the costs of social control over and reorganization (modernization, liquidation) of public forms, and (opportunity) "costs" of public inaction".

The proposed analysis is to be made at different levels of agro-ecosystems (farm, area, microregion, macro-region, national, international), depending on the type of eco-challenge and the scale of the collective action needed to eliminate the specific problems and risks associated with the agroecosystems and their services. Identification and evaluation of the dominating specific forms of governance of agro-ecosystem services of a given type in a particular country, macro and microregion, etc. is to be a subject to special "micro" multidisciplinary study. They require a multidisciplinary approach and use of diverse information for the eco-state, risks, public programs and measures, scientific, statistical and forecast data for the development of ecosystems, etc., as well as the collection of new micro and macro information on forms, the costs, factors, effects and intentions of the agents involved in the managing the services of agro-ecosystems at the relevant hierarchical levels.

The analyses and improvement of the governance of agroecosystem services is not a one-off act that ends with a perfect system for governance of agroecosystem services at the final stage. Rather, it is a permanent process that should improve the eco-governance along with the evolution of the natural environment, individual and collective (social) knowledge and preferences, and the modernization of technology and the institutional environment. Moreover, the public (local, national, international) failure is possible (and often prevail), leading us again to the next cycle of improving the eco-governance in agriculture. In some cases, it is not at all impossible to "affect" the natural environment through (agro) management and the effective adaptation is the only possible strategy for overcoming environmental consequences for agricultural and other sectors of human activity.

The proposed comparative institutional analysis also allows us to anticipate the probable cases of new public (local, national, international) as a result of the inability to mobilize sufficient political support and the necessary resources and or ineffective implementation of otherwise "good" policies in socio-economic conditions of a particular country, macro or micro agroecosystem. As public failure is a practically feasible option, its timely detection allows to anticipate the existence or deepening of certain environmental problems and to inform the (local, international) community about the risks involved.

\footnotetext{
16 The value of some eco-losses can be expressed in economic terms (reduction of income in related industries, replacement and recovery costs, negative impact on human well-being, etc.), while a significant part of the social costs cannot be expressed in monetary terms (the negative impact on biodiversity, other ecosystems, human health and life, future generations, etc.).
} 


\section{Conclusions}

The study of the forms, factors and efficiency of the governance of agro-ecosystem services in Bulgaria is at an early stage. In this "new" area, many traditional economic approaches and models are "not working" well, and multidisciplinary and interdisciplinary analysis is needed in which economists have to contribute. "Empirical" research is also to be initiated to "test" and improve the theory, and effectively support policies and farming strategies and practices. This requires the collection of new types of micro and macro information on the personal characteristics of participants in the "production" and consumption of agro-ecosystem services, for the type and forms of their relationships, for the specific socio-economic and institutional environment, and for the agro-ecosystems of different types. and their diverse "services" at different levels and horizons of management. 


\section{References}

Башев Х. (2009): Управление на услугите на агро-екосистемите, Икономика и управление на селското стопанство No 6, 3-20.

Башев X. (2012): Ефективност на фермите и аграрните организации, Икономическа мисъл, бр. 4, 46-77.

Башев X. (2012): Управление на аграрния риск, Икономическа мисъл, 50-75

Башев X. (2014): Екоуправление в селското стопанство, Икономическа мисъл, бр.1, 29-55.

Башев X. (2016): Устойчивост на фермата, сп. Икономика 21, 22-58.

Башев X. (2018): Влияние на институционалната среда върху аграрната устойчивост в България, Икономическа мисъл, 4, 3-32.

Башев Х., Б. Иванов, Д. Тотева (2019): Оценка на социално-икономическата и екологична устойчивост на аграрните екосистеми в България, Икономическа мисъл, бр.2, 33-56.

Башев X., М. Михайлова (2019): Състояние и развитие на системата за обучение и съвети в селското стопанство на България, Икономика и управление на селското стопанство, бр 3, 21-41.

Башев Х., М. Михайлова (2019): Състояние и развитие на аграрната научноизследователска и развойна дейност в България, Икономика и управление на селското стопанство, бр 3, 3-22.

Башев Х., М. Михайлова (2019): Състояние, ефективност и фактори за развитие на системата за споделяне на знания, иновации и дигитализация в селското стопанство, Икономика и управление на селското стопанство, бр 4.

ИАОС (2019): Екосистеми и екосистемни услуги, Изпълнителната агенция по околна среда (ИАОС).

Йорданов Я., Д. Михалев, В. Василев, С. Братанова- Дончева, К. Гочева, Н. Чипев (2017): Методика за оценка и картиране на състоянието на земеделските екосистеми и техните услуги в българия, ИАОС.

Казакова Я. (2016): Земеделие с висока природна стойност (обучение, иновации, знания), УHCC.

Недков С. (2016): КОНЦЕПЦИЯ ЗА Екосистемни услуги, Презентация, работна среща 31 май 2016г.

Николов С. (2018): Екосистемни услуги и тяхното оценяване - кратък преглед, Journal of the Bulgarian Geographical Society, Volume 39, 51-54.

Тодорова К. (2017): Управление на риска от наводнения чрез екосистемни услуги от земеделските стопанства, Дисертация, УНСC, WWF (2019): Екосистемите и техните „услуги”, WWF.

Чипев Н., Св. Братанова - Дончева, К. Гочева, М. Жиянски, М. Мондешка, Я. Йорданов, И. Апостолова, Д. Сопотлиева, Н. Велев, Е. Рафаилова, Й. Узунов, В. Карамфилов, Радка Фикова, Ст. Вергиев (2017): Методологична рамка за оценка и картиране на състоянието на екосистемите и екосистемните услуги в българия ръководство за 
мониторинг на състоянието и развитието на екосистемите и екосистемните услуги, ИАОС.

Adhikari B. and G. Boag (2013): Designing payments for ecosystem services schemes: some considerations, Current Opinion in Environmental Sustainability 2013, 5:72-77.

Allen J., J.y DuVander, I. Kubiszewski, E. Ostrom (2011): Institutions for Managing Ecosystem Services Solutions, Vol. 2, 6, 44-49.

Bachev H. and M. Labonne (2000): About the organization of agrarian innovations, INRA.

Bachev H. (2008): Integration of dairy farms in the supply chain in Bulgaria, Society and Economy 30 (1), 93-109.

Bachev H. (2009): Governing of Agro-ecosystem Services. Modes, Efficiency, Perspectives, VDM Verlag.

Bachev H. (2009): MODES OF GOVERNANCE OF ECOSYSTEM SERVICES, IUP Journal of Governance \& Public Policy 4.

Bachev H. (2009): Understanding Efficiency of Agrarian Organization, Annals of the University of Petrosani - Economics 9 (1), 27-42.

Bachev H. (2010): Framework for Analysis of Agrarian Contracts, Management Research and Practice 2 (1), 39-66.

Bachev H (2011): Management of Agro-Ecosystem Services: Framework of Analysis, Case of Bulgaria, in J. Daniels (editor), Advances in Environmental Research. Vol. 17, New York: Nova Science, 119-164.

Bachev H. (2011): Governing of Chemical and Biological Risks in Agri-food Sector: Modes, Efficiency, Challenges, in Exploring Multidiciplinary Approaches to Chemical and Biological Defence, Proceedings, DTRA \& IIBR Workshop.

Bachev H. (2012): Governing of Agro-Ecosystem Services in Bulgaria, in A. Rezitis (editor), Research Topics in Agricultural and Applied Economics, Vol. 3, Bentham Science Publisher, 94-129.

Bachev H. (2013): New Approach for Assessing and Improvement of Environmental Management and Strategies in Agri-business, Global Journal of Management And Business Research, Volume 13, Issue 7.

Bachev H. (2013): Risk Management in Agri-food Sector, Contemporary Economics, Vol. 7 (1), 45-62.

Bashev H. (2016): Defining and assessment of sustainability of farms, Economic Studies Journal, 158-188.

Boelee, E. (Editor) (2013): Managing water and agroecosystems for food security, CABI.

Coase R. (1960): The Problem of Social Cost, Journal of Law and Economics, Vol. 3, 1-44.

De Groot R., Wilson M, Boumans R. (2002): A typology for the description, classification and valuation of ecosystem functions goods services. Ecol Econ 41:393-408

EEA (2015): Ecosystem services in the EU, European Environment Agency.

FAO (2016): Mainstreaming ecosystem services and biodiversity into agricultural production and management in East Africa, Technical guidance document, FAO. 
Fremier A., F. DeClerck, N.Bosque-Pérez, N. Carmona, R, Hill, T. Joyal, L. Keesecker, P. Klos, A. Martínez-Salinas, R. Niemeyer, A. Sanfiorenzo, K. Welsh, J. Wulfhorst (2013): Understanding Spatiotemporal Lags in Ecosystem Services to Improve Incentives, BioScience Vol. 63 No. 6.

Furuboth E. \& Richter R. (1998): Institutions and Economic Theory: The Contribution of the New Institutional Economics. Ann Arbor: The University of Michigan Press.

Gao H., T. Fu, J. Liu, H. Liang and L. Han (2018): Ecosystem Services Management Based on Differentiation and Regionalization along Vertical Gradient, China, Sustainability, 10, 986

Garbach K., J. Milder, M Montenegroand, F. DeClerck (2014): Biodiversity and Ecosystem Services in Agroecosystems, Elsevier.

Gemmill-Herren B. (2018): Pollination Services to Agriculture Sustaining and enhancing a key ecosystem service, Routledge.

Grigorova Y. \& Kazakova Y. (2008): High Nature Value farmlands: Recognizing the importance of South East European landscapes, Case study report, Western Stara Planina, WWF (EFNCP).

Habib T., S. Heckbert, J. Wilson, A.Vandenbroeck, J. and D. Farr (2016): Impacts of land-use management on ecosystem services and biodiversity: an agent-based modelling approach. PeerJ 4:e2814.

INRA (2017): A framework for assessing ecosystem services from human-impacted ecosystems. EFESE,

Kanianska R. (2019): Agriculture and Its Impact on Land-Use, Environment, and Ecosystem Services, INTECH.

Laurans Y. and L.Mermet (2014): Ecosystem services economic valuation, decision-support system or advocacy? Ecosystem Services, Vol. 7, 98-105.

Lescourret F., D. Magda, G. Richard, A. Adam-Blondon, M. Bardy, J. Baudry, I. Doussan, B. Dumont, F. Lefèvre, I. Litrico, R. Martin-Clouaire, B. Montuelle, S. Pellerin, M. Plantegenest, E. Tancoigne, A.Thomas, H. Guyomard, J. Soussana (2015): A socialecological approach to managing multiple agro-ecosystem services, Current Opinion in Environmental Sustainability, Vol. 14, 68-75.

Marta-Pedroso C., L. Laporta, I. Gama, T. Domingos (2018): Economic valuation and mapping of Ecosystem Services in the context of protected area management, One Ecosystem 3: e26722,

MEA (2005): Millennium Ecosystem Assessment, Ecosystems and Human Well-being, Island Press, Washington, DC.

Munang R., I. Thiaw, K. Alverson, J. Liu and Z. Han (2013): The role of ecosystem services in climate change adaptation and disaster risk reduction, Current Opinion in Environmental Sustainability, 5:47-52.

North D. (1990): Institutions, Institutional Change and Economic Performance. Cambridge: Cambridge University Press. 
Novikova A., L. Rocchi, V. Vitunskienè (2017): Assessing the benefit of the agroecosystem services: Lithuanian preferences using a latent class approach, Land Use Policy, Vol. 68, 277-286.

Nunes P., P. Kumar, T. Dedeurwaerdere (2014): Handbook on the Economics of Ecosystem Services and Biodiversity, Edward Elgar, Cheltenham.

Power, A. (2010): Ecosystem services and agriculture: Tradeoffs and synergies. Philos. Trans. R. Soc. Lond. B Biol. Sci. 365, 2959-2971.

Scholes R, B. Reyers, R. Biggs, M. Spierenburg and A. Duriappah (2013): Multi-scale and crossscale assessments of social-ecological systems and their ecosystem services, Current Opinion in Environmental Sustainability, 5:16-25.

Todorova K. (2017): Adoption of ecosystem-based measures in farmlands - new opportunities for flood risk management, Trakia Journal of Sciences, Vol. 15, 1, 152-157.

Tsiafouli M., E. Drakou, A. Orgiazzi, K. Hedlund and K. Ritz (2017): Optimizing the Delivery of Multiple Ecosystem Goods and Services in Agricultural Systems, Frontiers in Ecology and Evolution, vol.5, art. 9715

UN (2005). The Millennium Development Goals Report. United Nations, New York.

Van Oudenhoven, A. (2020): Quantifying the effects of management on ecosystem services, https://www.wur.nl/en/show/Quantifying-the-effects-of-management-on-ecosystemservices.htm

Petteri V., D. D’Amato, M. Forsius, P. Angelstam, C. Baessler, P. Balvanera, B. Boldgiv, P. Bourgeron, J. Dick, R. Kanka, S. Klotz, M. Maass, V. Melecis, P. Petrı, H. Shibata, J. Tang, J. Thompson and S. Zacharias (2013): Using long-term ecosystem service and biodiversity data to study the impacts and adaptation options in response to climate change: insights from the global ILTER sites network, Current Opinion in Environmental Sustainability 2013, 5:53-66.

Wang S., B. Fu, Y. Wei, C. Lyle (2013): Ecosystem services management: an integrated approach, Current Opinion in Environmental Sustainability, 5:11-15.

Williamson O. (1985): The economic institutions of capitalism. Simon and Schuster.

Wood S., D. Karp, F. DeClerck, C. Kremen, S. Naeem, C. Palm (2015): Functional traits in agriculture: agrobiodiversity and ecosystem services, Trends in Ecology \& Evolution, 1-9.

Zhan J. (Editor) (2015): Impacts of Land-use Change on Ecosystem Services, Springer. 